\title{
Internal reinforcement of laminated duo beams of low-grade timber with GFRP sheets
}

\author{
L.A. Basterra *, J.A. Balmori, L. Morillas, L. Acuña, M. Casado \\ Research group of Timber Structures and Wood Technology, University of Valladolid, Avenida de Salamanca, 18, 47014 Valladolid, Spain
}

\section{H I G H L I G H T S}

- We tested low-grade duo glulam GFRP internally reinforced timber beams.

- Reinforced glulam beams have higher ultimate load capacity.

- Reinforced beams show improvements in stiffness and ultimate moment capacity.

\section{A R T I C L E I N F O}

\section{Article history:}

Received 22 February 2017

Received in revised form 14 July 2017

Accepted 2 August 2017

Available online 10 August 2017

\section{Keywords:}

Low-grade timber

Glass fibre reinforced polymer (GFRP)

Duo glulam

Populus $\times$ euroamericana I-214 wood

\begin{abstract}
A B S T R A C T
The purpose of this work is to study the flexural behaviour of Populus $\times$ euroamericana I-214 low-grade glulam timber beams, internally reinforced with Glass Fibre Reinforced Polymer (GFRP). To this end, 30 unreinforced beams and 60 reinforced beams, with two ratios of GRFP reinforcement, were produced and tested. Results show an improvement in the flexural behaviour of reinforced beams, with noticeable increases in stiffness (MOE) and ultimate moment capacity (MOR). By using relatively low reinforcement ratios $(1.07 \%, 1.6 \%)$ in the tension zone, we have measured an average improvement of $12.1 \%$ and $14.7 \%$ in stiffness, and an increase up to $23 \%$ in moment capacity. GFRP reinforced seems to reduce the influence of timber heterogeneity and singularities (knots, cracks ...), which translates into less scattered results and better characteristic values.
\end{abstract}

(c) 2017 Elsevier Ltd. All rights reserved.

\section{Introduction}

The use of fibre-reinforced polymer (FRP) reinforcements in the renovation and repair of civil structures is widespread [1]. However, their use in the manufacture of new wood-based products has been poorly developed. Progress in wood engineering since the 1940s has been based on wood-based composite products, such as laminated beams, microlaminated beams (LVL), rebuilt wood (LSL and PSL) and wood-based laminates (CLT) [2], without resorting to new materials, except in isolated cases such as $\mathrm{FiRP}^{\circledR}$ reinforced glulam technology.

The introduction of reinforcements based on FRPs in the manufacture of laminated beams allows the use of low-grade woods and fast-growing species for structural purposes, which increases the strength and flexural rigidity of the beams and reduces the variability of mechanical properties [3]. In this way, these lower-cost woods present an economically viable commercial alternative with smaller sections, lower weight and desirable mechanical

\footnotetext{
* Corresponding author.

E-mail address: basterra@arq.uva.es (L.A. Basterra).
}

properties. Of the available reinforcing fabrics, unidirectional glass fibre (E-Glass) reinforced polymers (GFRPs) seem the most appropriate because of their low cost and suitable mechanical properties [4]. In addition, they are resistant to corrosion, are poor electrical conductors and weigh approximately four times less than steel.

In the present study, the duo type of laminated beam is used because it is the most basic industrialisation system. The GFRP reinforcement is introduced into the glue line, inside the section, during lamination of the duo beams. In this way, it improves the fire resistance of the reinforcement [5] compared to FRP external reinforcements because the exposure of the glue line to high temperatures limits its stability [6]. In addition, this arrangement allows the manufacture of beams with the same apparent section and different levels of performance by varying the weight of the interior reinforcement without any visual impact.

\section{State of the art}

The use of high elastic modulus FRPs for the reinforcement of pieces of wood subjected to flexion has been studied by many researchers [7]. The first studies, which were conducted by 
Theakston [8] on GFRP-reinforced laminated beams of Douglas pine, Pseudotsuga menziesii (Mirb.) Franco, demonstrated the potential of such reinforcement. These and other initial contributions from the 1960s to 1970s have been analysed by Bulleit [9].

Since the 1990s, the number of studies of FRP-reinforced timber has markedly increased. Moulin [10] tested GFRP-reinforced poplar beams and confirmed the suitability of this type of reinforcement in low-grade species. Triantafillou [11] conducted numerous tests of external FRP reinforcements and obtained a considerable increase in the strength, stiffness or ductility of reinforced wood elements. Dagher et al. [12] tested laminated beams of different wood grades with varying types and quantities of FRP and concluded that low-grade reinforced wood can compete commercially with higher-quality timber. Tingley [13], in tests of FRP-reinforced beams, also proposed the use of low-grade wood with FRPs in place of high-grade wood. Hernández et al. [14] reinforced laminated beams of Liriodendron tulipifera L. (yellow poplar) with external GFRP reinforcements placed in tension, as well as in tension and compression; the results showed that tensile reinforcement increases flexural strength, whereas double reinforcement increases flexural stiffness. Johns and Lacroix [15] compared CFRP and GFRP reinforcements in sawnwood beams; the increases in strength that resulted varied from 40 to $100 \%$ depending on the type of reinforcement. Fiorelli and Alves [16] tested lumber beams reinforced with GFRP and CFRP and found significant improvements with both types of reinforcement. Borri et al. [17] studied the reinforcement of old wood beams with CFRP in different configurations and amounts; the results of the tests showed improvements in flexural stiffness of approximately 25-30\%. Nadir et al. [18] tested low-grade sawn timber reinforced with GFRP and CFRP of different thicknesses and placed in the tension zone.

More recently, other research has been conducted on internal FRP reinforcement of wood using bars and sheets. Gentile et al. [19] tested beams reinforced with near-surface-mounted GFRP bars with different diameters arranged in the tension zone; the results indicated that the GFRP reinforcement allows the section to be homogenised, compensating for local defects in the wood. Schober and Rautenstrauch [20] tested old wood beams with CFRP reinforcement and compared vertical and horizontal external and internal reinforcements. Jasiénko and Nowak [21] analysed the internal reinforcement of existing wood beams of historical value (polychromed) by introducing CFRP. Kliger et al. [22] compared laminated beams that were internally reinforced with steel strips and CFRP strips. Ribeiro et al. [23] proposed the commercial manufacture of GFRP-reinforced laminated beams of Pinus pinaster Ait. (maritime pine) as a new product in the wood industry. Parvez et al. [24] compared internal steel reinforcement and different FRP reinforcements applied to sawnwood beams; they concluded that GFRP reinforcements provide the best increase in flexural strength compared to steel and CFRP reinforcements. Raftery and Harte [25] proposed the introduction of GFRP in the last glue line in low-grade timber beams; they found a $40 \%$ improvement in the stiffness for reinforcement ratios between 1.10 and $1.25 \%$. Continuing with this line of work, Fiorelli and Alves [26] presented a study of laminated beams reinforced with GFRP in the last glue line. Raftery and Whelan [27] studied the internal reinforcement of low-grade wood laminated beams with GFRP bars in various configurations; with reinforcement ratios of $1.4 \%$ in tension, they found increases in stiffness of $11-14 \%$ that reached $22-29 \%$ when was also reinforced in compression. Along this same line, Fossetti et al. [28] tested laminated beams internally reinforced by GFRP and CFRP bars in the tension zone. Raftery and Kelly [29] conducted an experimental programme for testing low-grade glued laminated timber reinforced with bonded-in basalt FRP rods. Yang et al. [30] tested Douglas pine beams reinforced with different types of internal reinforcement made from GFRP, CFRP and steel.
However, there are few studies in which GFRP reinforcements are placed vertically, as tested in this article. The reason that there are not so many studies with vertical reinforcement could be due to the fact that this orientation is much less structurally efficient than when the reinforcement is horizontal and placed near the tension face. Nevertheless, it has other advantages as described in the introduction.

\section{Objectives}

This study is part of a programme of research whose general objective is the revaluation of fast-growing, low-cost timber species from sustainable plantations, such as the genus Populus. To do this, research is needed to characterise and understand its behaviour well to be able to normalise it and ensure that the processed product can be passed to the market. In this case, the specific objective is studying the efficiency of duo beams reinforced by rigid sheets of a GFRP, which offers a good balance between performance and cost, placed vertically within the section.

This type of wood, which grows quickly and easily with straight trunks and limited branching, exhibits a low and uncompetitive stiffness and strength, and for that reason it is currently allocated to secondary uses such as boards and papermaking. The use of new technologies of cultivation, sawing and transformation can increase its quality and thereby increase its commercial value. Specifically, Populus wood comes from widely grown sustainable forest plantations worldwide, and its revaluation can boost the economy and progress in large rural areas and thereby help the environment.

\section{Materials and methods}

\subsection{Timber}

In this study, poplar wood from the clone "Populus $\times$ euroamericana I-214" from the same sawmill and batch in an existing plantation in Berzosilla (Palencia, Spain) was used. The logs were transformed into boards $2500 \mathrm{~mm}$ in length with a nominal section of $140 \mathrm{~mm} \times 40 \mathrm{~mm}$. The planks were maintained under controlled hygrothermal conditions until the moisture content was less than $18 \%$. Before the duo beams were made, the wood was conditioned in the laboratory until a humidity close to $12 \%$ was reached.

Initially, solid wood characterisation tests were conducted on 30 unreinforced duo beams with nominal dimensions $125 \times 80 \times 2500 \mathrm{~mm}$ as shown in Fig. 1 to understand the performance of the wood used. The results are summarised in Table 1, which indicates the standard used to determine each property. Shear deformation is neglected in the calculation of modulus of elasticity. Values in Table 1 are similar to previous research on "Populus $\times$ euroamericana I-214" [31].

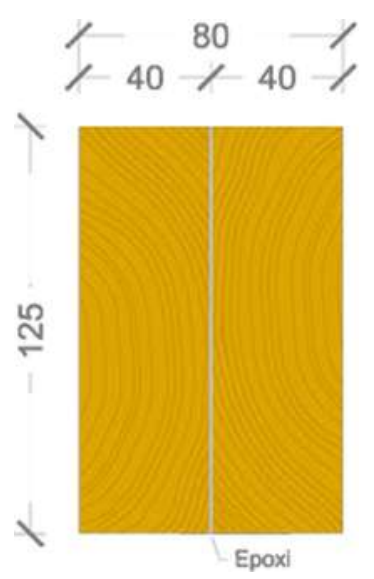

Fig. 1. Unreinforced glulam duo beam. 
Table 1

Properties of the wood used.

\begin{tabular}{|c|c|c|c|c|}
\hline Property & Mean & $5 \%$ perc. & $\operatorname{COV}(\%)$ & Standard \\
\hline Moisture content (\%) & 10.10 & 8.76 & $9.10 \%$ & EN 13183:2002 [32] \\
\hline Density $\left(\mathrm{kg} / \mathrm{m}^{3}\right)$ & 362.56 & 315.74 & $9.01 \%$ & EN 384:2010 [33] \\
\hline Modulus of elasticity (MOE, MPa) & 7835.0 & 6808.7 & $10.18 \%$ & EN 408:2011 [36] \\
\hline Modulus of rupture (MOR, MPa) & 36.02 & 21.07 & $25.51 \%$ & EN 408:2011 [36] \\
\hline
\end{tabular}
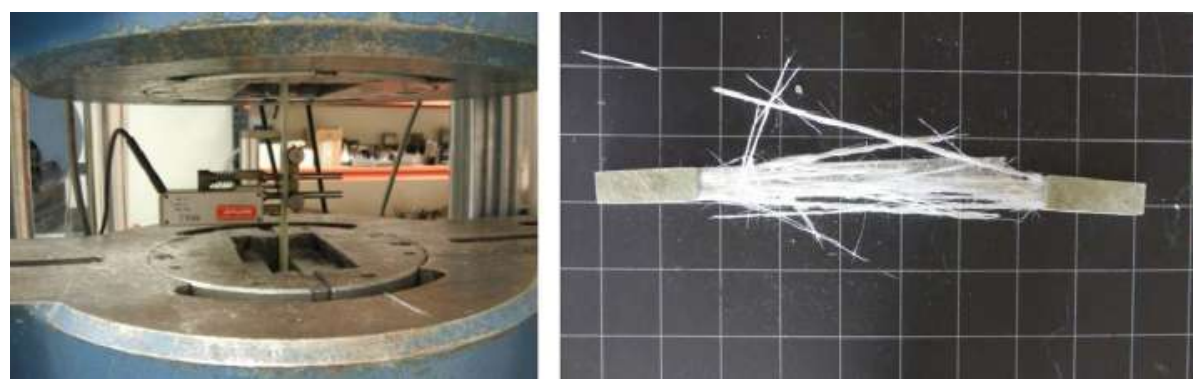

Fig. 2. GFRP tensile test according to ISO 527-5.

\subsection{GFRP}

Following ISO 527-5, rigid GFRP strips with a width of $15 \mathrm{~mm}$ and a length of $250 \mathrm{~mm}$ were fabricated using high-pressure vacuum infusion techniques from unidirectional 'E-Glass' fibre embedded in an isophthalic resin of unsaturated polyester. The ends of the specimen were reinforced with end tabs of $50 \times 15 \mathrm{~mm}$, according to ISO 527-5 (Fig. 2). Beforehand, the adhesion of the sheets was improved by smooth surface abrasion.

The GFRP sheets manufactured in this way were tensile tested according to ISO 527-5/B [34] in an INSTRON MEN-102/100 machine with an installed load cell of $1000 \mathrm{kN}$ equipped with pneumatic clamps (Fig. 2). To measure the unit strain, an IBERTEST IB-MFA 2 strain gauge with $2 \mathrm{~mm}$ of travel was used. A deformation rate of $1 \mathrm{~mm} / \mathrm{min}$ was applied.

The results of the tensile tests of the GFRP sheets are summarised in Table 2.

\subsection{Adhesive}

For lamination, Sikadur-30 epoxy resin, a bicomponent, thixotropic and solvent-free structural adhesive was used. This product is composed of a combination of epoxy resins and selected fillers, and is widely used in civil engineering. The incorporation of these selected fillers allowed the thickness of the glue line to be increased without altering the final mechanical properties of the bond. Preliminary tests were conducted in accordance with standard EN 56543 [35] verify the good behaviour of the joint between the wood and the sheets of GFRP.

\subsection{Test program}

Each reinforced duo beam was manufactured from two boards with nominal dimensions of $40 \times 140 \mathrm{~mm}$ with a tolerance of $\pm 2 \mathrm{~mm}$ after mechanical brushing, which, once adhered, formed a double beam with a total section of $80 \times 140 \mathrm{~mm}$. A recess was made in one of the boards to house the GFRP reinforcement without altering the final dimensions of the beam (Fig. 3a and b). Thirty (30) pieces of each type were manufactured and tested. The area of the reinforcement, compared to the total section, was $1.07 \%$ in those reinforced with $1200 \mathrm{~g} / \mathrm{m}^{2}$ GFRP and $1.6 \%$ in those reinforced with $2400 \mathrm{~g} / \mathrm{m}^{2}$ GFRP. By considering the transformed section method with a ratio of moduli of elasticity $E_{f} / M O E$ of 2.76 and 3.42, the inclusion of GFRP reinforcement translates into a theoretical increase of the flexural stiffness (EI) of $3.3 \%$ and $6.1 \%$.

During the adhesion process, the resin temperature and the maximum working time of the mixture were precisely controlled. Once the adhesive was spread, a uniform pressure of approximately $0.5 \mathrm{~N} / \mathrm{mm}^{2}$ was applied for $48 \mathrm{~h}$. The mean dose used was $1500 \mathrm{~g} / \mathrm{m}^{2}$ of epoxy resin.

\subsection{Experimental setup}

The reinforced duo beams were tested in a four-point bending test configuration in accordance with standard EN 408: 2011 [36]. The distance between supports was $2.2 \mathrm{~m}$ and the distance between the point loads was $0.84 \mathrm{~m}$. The global bending modulus of elasticity was obtained by recording the deformations measured during the test with a linear variable differential transformer (LVDT) located at the centre of the span. The tests were performed with a constant displacement speed of $12 \mathrm{~mm} / \mathrm{min}$. The section of the stress-strain curve for which the beam's stiffness was measured corresponded to between 10 and $40 \%$ of the estimated maximum load for all beams. When $40 \%$ of the estimated maximum load was reached, the LVDT was removed, and the test continued until failure. The beams broke after $300 \pm 120 \mathrm{~s}$. After breakage occurred, the failure mode was inspected, and its location and characteristics were recorded.

From each beam tested, a specimen with dimensions of $80 \times 140 \times 80 \mathrm{~mm}$ was extracted, and its moisture content and density were obtained [32]. With knowledge of the humidity of each beam tested, the bending modulus of elasticity obtained could be corrected by applying the corrections proposed in standard EN $384: 2010$ [33].

\section{Results and discussion}

\subsection{Load-deflection behaviour and failure modes}

Regardless of the reinforcement, all the beams tested exhibited essentially linear elastic behaviour until breaking, except for the initial loading section and the final section of loading before breakage. Failure started in defects or irregularities of the wood (knots, fibre deviation, etc.). No signs of plastification were detected in the compression zone, nor were adhesion failures found in the glue line of any of the beams. The typical breakage pattern of unreinforced beams is shown in Fig. 4. According to the properties of wood in Table 1 , the fracture of $80 \times 140 \mathrm{~mm}$ non-reinforced beams occurs at a load of $27.6 \mathrm{kN}$ and an average deformation of $34.6 \mathrm{~mm}$.

The load-deflection behaviour of duo beams reinforced with $1200 \mathrm{~g} / \mathrm{m}^{2}$ GFRP showed a significant increase in the load capacity of the beams, with breaks at a load of $32.6 \mathrm{kN}$ and ultimate

Table 2

Mean results and coefficient of variation (COV) of the MOE and MOR in the tensile tests of the GFRP.

\begin{tabular}{|c|c|c|c|c|c|}
\hline Weight $\left(\mathrm{g} / \mathrm{m}^{2}\right)$ & Number of specimens & Young's modulus $\mathrm{E}_{\mathrm{f}}(\mathrm{GPa})$ & $\operatorname{cov}(\%)$ & Ultimate tensile strength (MPa) & $\operatorname{COV}(\%)$ \\
\hline 1200 & 20 & 21.61 & 4.43 & 455 & 6.26 \\
\hline 2400 & 20 & 26.82 & 8.35 & 568 & 7.64 \\
\hline
\end{tabular}




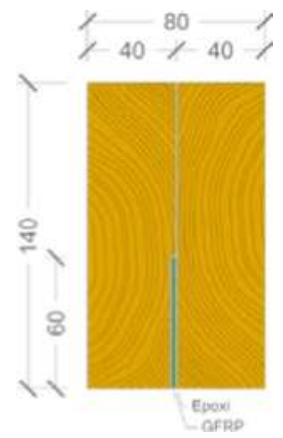

(a) GFRP-reinforced $\left(1200 \mathrm{~g} / \mathrm{m}^{2}\right)$ glulam beam

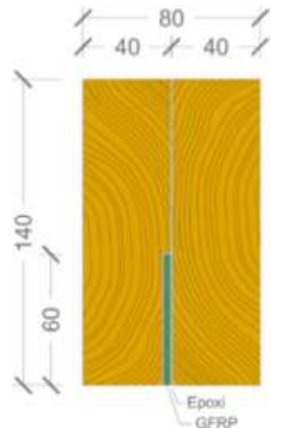

(b) Doubly GFRP-reinforced $\left(2400 \mathrm{~g} / \mathrm{m}^{2}\right)$ glulam beam.

Fig. 3. Tested beam section configurations.

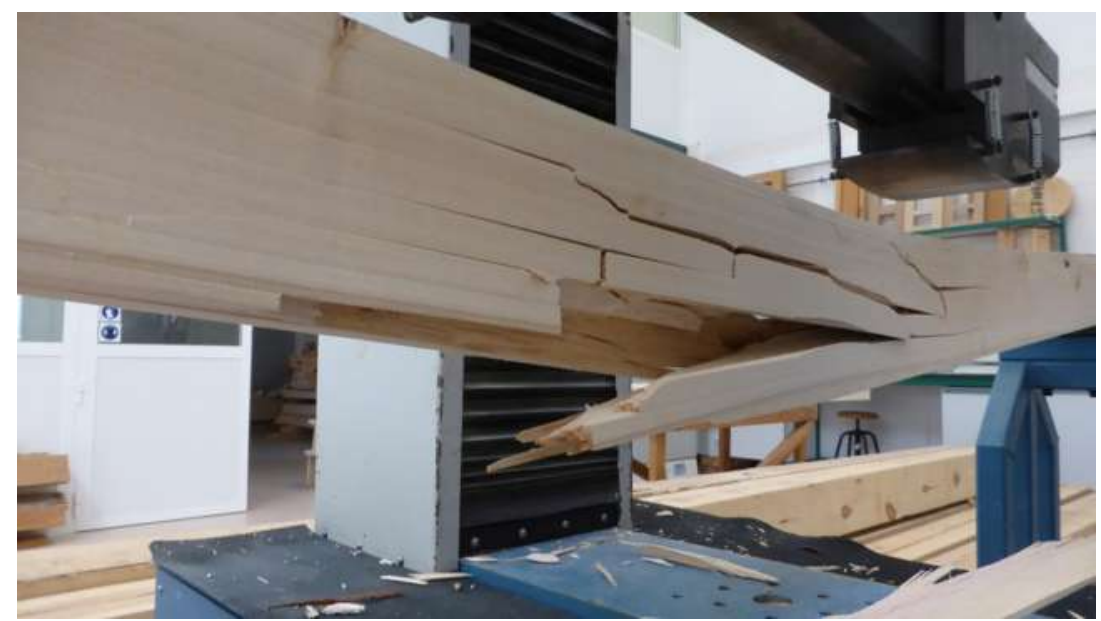

Fig. 4. Unreinforced beam failure

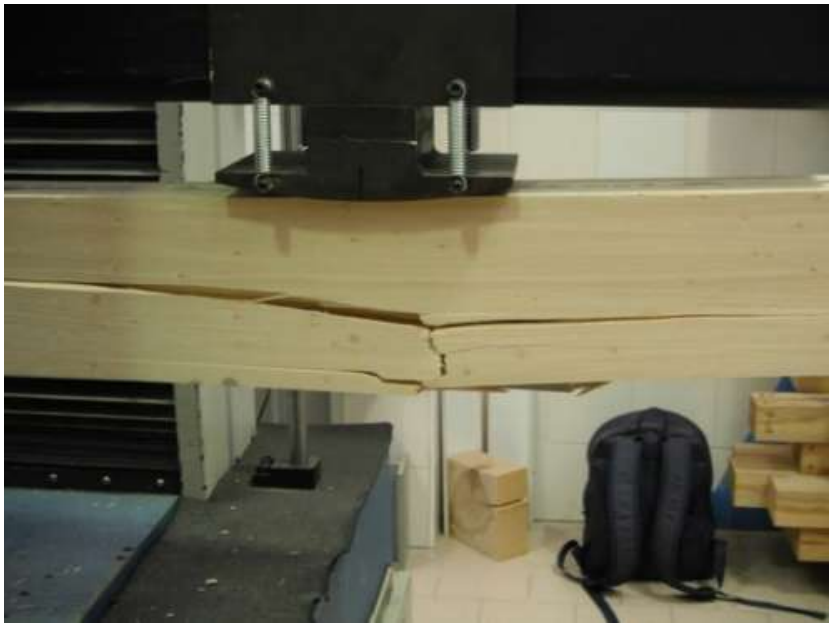

Fig. 5. Beam reinforced with $1200 \mathrm{~g} / \mathrm{m}^{2} \mathrm{GFRP}$ at failure.

deformation of $41.3 \mathrm{~mm}$. As in the previous case, breakage occurred in the tension zone (Fig. 5). No signs of plastification were observed in the compression zone of the beam and the woodGFRP-wood adhesion displayed the correct behaviour, without

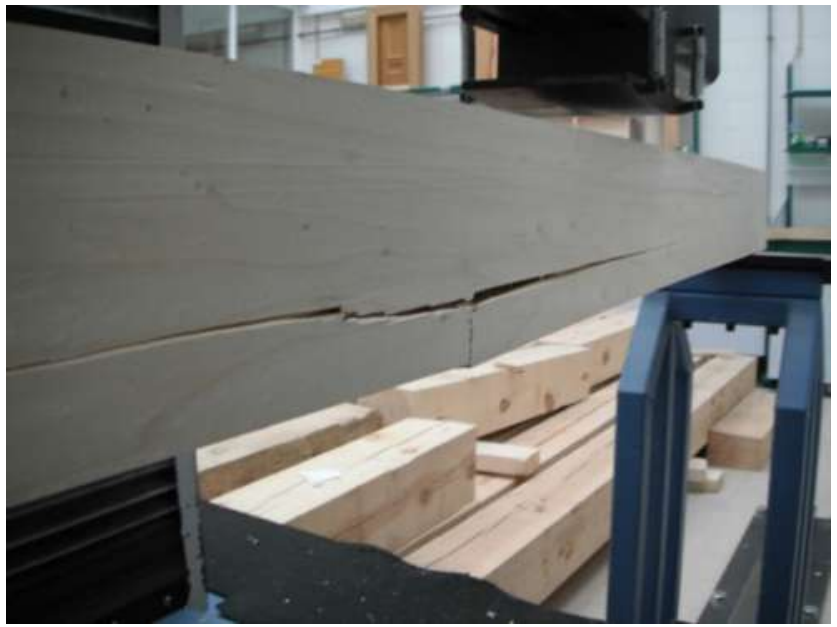

Fig. 6. Beam reinforced with $2400 \mathrm{~g} / \mathrm{m}^{2} \mathrm{GFRP}$ at failure.

adhesion failures during the test, except in 2 of the 30 beams tested, which failed after the wood collapsed.

In the beams reinforced with $2400 \mathrm{~g} / \mathrm{m}^{2} \mathrm{GFRP}$, the increase in the amount of fibre had no significant effect on the final breaking 
Table 3

Ultimate load and deflection of the beams.

\begin{tabular}{|c|c|c|c|c|}
\hline Description & $\mathrm{n}$ & $\begin{array}{l}\text { Ultimate load } \mathrm{F}_{\mathrm{ult}}(\mathrm{kN}) \\
\text { Experimental } \\
\text { Mean } \pm \mathrm{SD}\end{array}$ & $\begin{array}{l}\text { Ultimate deflection (mm) } \\
\text { Theoretical }\end{array}$ & $\begin{array}{l}\text { Ultimate deflection }(\mathrm{mm}) \\
\text { Experimental } \\
\text { Mean } \pm \text { SD }\end{array}$ \\
\hline Unreinforced glulam beam $80 \times 140 \mathrm{~mm}$ & 30 & $27.6 \pm 7.02$ & 34.6 & $34.6 \pm 8.10$ \\
\hline Reinforced glulam beam (GFRP sheet of $1200 \mathrm{~g} / \mathrm{m}^{2}$ ) & 30 & $32.57 \pm 4.32$ & 39.5 & $41.34 \pm 10.25$ \\
\hline Reinforced glulam beam (GFRP sheet of $2400 \mathrm{~g} / \mathrm{m}^{2}$ ) & 30 & $34.13 \pm 4.66$ & 40.3 & $44.30 \pm 9.17$ \\
\hline
\end{tabular}

Table 4

Mean value, COV and improvement in bending stiffness (EI).

\begin{tabular}{|c|c|c|c|c|c|}
\hline Description & $\mathrm{n}$ & $\begin{array}{l}\text { EI }\left(\mathrm{kN} \cdot \mathrm{m}^{2}\right) \\
\text { Theoretical }\end{array}$ & $\begin{array}{l}\text { EI }\left(\mathrm{kN} \cdot \mathrm{m}^{2}\right) \\
\text { Experimental } \\
\text { Mean } \pm \mathrm{SD}\end{array}$ & Improvement (\%) & $\operatorname{cov}(\%)$ \\
\hline Unreinforced glulam beam $80 \times 140 \mathrm{~mm}$ & 30 & 143.33 & $143.33 \pm 14.45 \mathrm{a}$ & - & 9.91 \\
\hline Reinf. glulam beam (GFRP sheet of $1200 \mathrm{~g} / \mathrm{m}^{2}$ ) & 30 & 148.14 & $160.62 \pm 12.88 \mathrm{~b}$ & 12.1 & 8.33 \\
\hline Reinf. glulam beam (GFRP sheet of $2400 \mathrm{~g} / \mathrm{m}^{2}$ ) & 30 & 152.09 & $164.34 \pm 19.46 \mathrm{c}$ & 14.7 & 11.56 \\
\hline
\end{tabular}

The different letters $(a, b, c)$ indicate significant differences $(p<0.05)$.
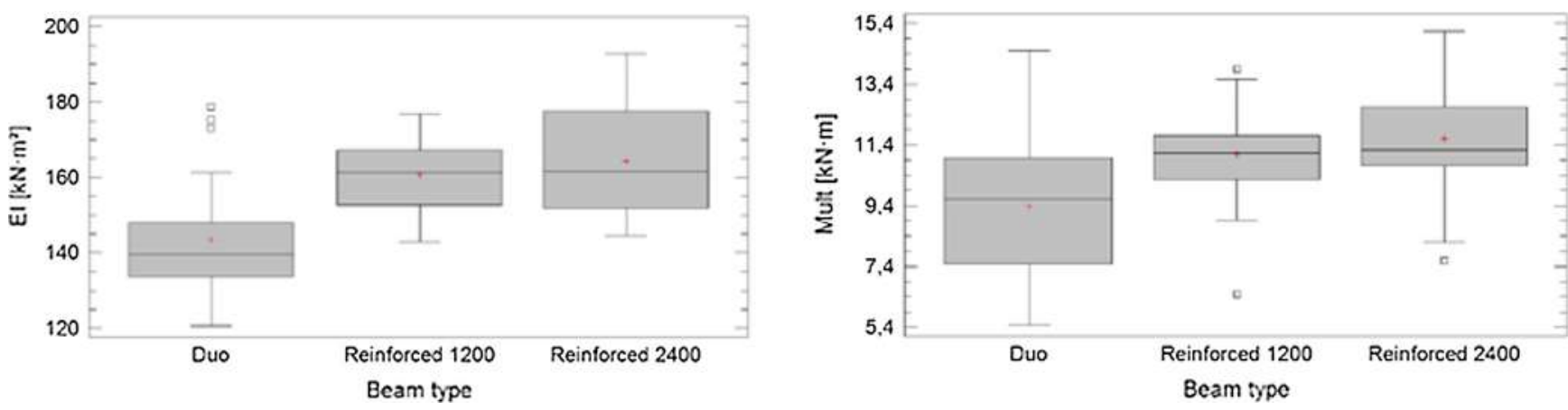

Fig. 7. Bending stiffness and ultimate moment capacity box-plots.

Table 5

Descriptive statistics and ANOVA of the mean, COV and improvement in the ultimate moment capacity.

\begin{tabular}{|c|c|c|c|c|}
\hline Description & $\mathrm{n}$ & $\begin{array}{l}\mathrm{M}_{\mathrm{ult}}(\mathrm{kN} \cdot \mathrm{m}) \\
\text { Mean } \pm \mathrm{SD}\end{array}$ & Improvement (\%) & $\operatorname{COV}(\%)$ \\
\hline Unreinforced glulam beam & 30 & $9.40 \pm 2.39 \mathrm{a}$ & - & 25.02 \\
\hline Reinforced glulam beam with GFRP sheet of $1200 \mathrm{~g} / \mathrm{m}^{2}$ & 30 & $11.08 \pm 1.47 \mathrm{~b}$ & 17.9 & 13.28 \\
\hline Reinforced glulam beam with GFRP sheet of $2400 \mathrm{~g} / \mathrm{m}^{2}$ & 30 & $11.60 \pm 1.58 \mathrm{~b}$ & 23.4 & 13.32 \\
\hline
\end{tabular}

The different letters $(a, b)$ indicate significant differences $(p<0.05)$.

Table 6

One-way ANOVA for the three beam groups' bending stiffnesses and ultimate moment capacities.

\begin{tabular}{|c|c|c|c|c|c|c|c|c|c|}
\hline \multirow[t]{2}{*}{ Source of variation } & \multirow[t]{2}{*}{ df } & \multicolumn{4}{|c|}{ Bending stiffness, EI $\left(\mathrm{kN} \cdot \mathrm{m}^{2}\right)$} & \multicolumn{4}{|c|}{ Ultimate moment capacity, $\mathrm{M}_{\mathrm{ult}}(\mathrm{kN} \cdot \mathrm{m})$} \\
\hline & & SS & MS & F ratio & $P$ value & SS & MS & F ratio & $P$ value \\
\hline Between groups & 2 & 14346.2 & 7173.12 & 44.53 & 0.0000 & 166.527 & 83.263 & 20.46 & 0.0000 \\
\hline Within groups & 84 & 13530.9 & 161.082 & & & 341.832 & 4.069 & & \\
\hline Total & 86 & 27877.2 & & & & 508.359 & & & \\
\hline
\end{tabular}

strength $(34.1 \mathrm{kN})$ at an ultimate deformation of $44.3 \mathrm{~mm}$. As in the previous series, the beams failed by tensile fracture on the underside (Fig. 6); there were signs of plastification on the compressed face in a single case. No adhesion problems were detected in the glue line.

As summarised in Table 3, the incorporation of GFRP reinforcement in the tension zone of the duo beams produced a significant increase in the load capacity, which coincided with those published by other authors (Hernández et al. [14], Jons and Lacroix [15], Fiorelli and Alves [16], Borri et al. [17] and Parvez et al.
[24], among others). Finally, the ultimate deformation increased moderately (41.34-44.30 mm), because it was limited by tensile failure of the wood. Theoretical ultimate deflection is calculated by assuming linear elastic behaviour and theoretical values of the bending stiffness EI. The fact that reinforced beams have larger ultimate deformation means that the incorporation of GFRP reinforcement allows for greater tensile strains and stresses in the wood. At failure, the MOR in unreinforced beams is $36 \mathrm{MPa}$, while wood in reinforced beams reached to average tensile stresses of 42.4 MPa (17.8\%) and 42.8 MPa (18.9\%). 


\subsection{Bending stiffness}

Because the sections were composed of two materials with initial elastic behaviour, the flexural stiffness of each beam could be expressed as a product, EI, which was obtained experimentally from the load and the deformation of the beam at $10 \%$ and at $40 \%$ of its capacity. Theoretical values are obtained by the transformed section method [37]. Table 4 and Fig. 7 summarise the experimental data obtained.

The results of beams reinforced with $1200 \mathrm{~g} / \mathrm{m}^{2}$ GFRP presented a significant improvement in their stiffness $(12.1 \%)$ and a lower dispersion; these results were comparable to those of other investigations involving GRFP by Raftery and Harte [25] and Raftery and Whelan [27] with similar reinforcement ratios, although the position of the reinforced is quite different. The beams reinforced with $2400 \mathrm{~g} / \mathrm{m}^{2}$ GFRP exhibited not much greater increases in the product EI (14.7\%), although its COV was somewhat higher (11.56\%).

\subsection{Ultimate moment capacity}

From the ultimate breaking force $\mathrm{F}_{\text {ult }}$, the ultimate moments $\left(\mathrm{M}_{\mathrm{ult}}\right)$ of each beam tested were obtained as $\mathrm{M}_{\mathrm{ult}}=0.5 * \mathrm{~F}_{\mathrm{ult}} * \mathrm{~d}$, where $d=680 \mathrm{~mm}$ was the distance between the point load and the support. The results are summarised in Table 5.

Fig. 7 summarises the resulting ultimate flexural capacity; it shows the mean, maximum, minimum, and 25th and 75th percentiles of the data. The results showed lower dispersions in the moment capacity, but similar dispersion in bending stiffness.

In the statistical analysis, the normality of the data was verified for all populations using the Kolmogorov-Smirnov normality test with Lilliefors correction, the Shapiro-Wilk test and a Q-Q normal probability plot; we were able to assume normality in all cases. The homoscedasticity condition was also met, and Barlett's test and Levene's test were analysed. Multiple comparison tests for the determination of homogeneous groups were performed using the Tukey's HSD test.

Based on the one-way ANOVA performed on the bending stiffness and the ultimate moment capacity to detect differences between groups of beams, Table 6 confirms that there were significant differences (at 95\%) between the 3 groups.

The comparative analysis of the two groups of reinforced pieces, those with $1200 \mathrm{~g} / \mathrm{m}^{2}$ GFRP and those with $2400 \mathrm{~g} / \mathrm{m}^{2}$ GFRP, which used the Tukey HSD and Fisher LSD tests, showed that there were statistically significant differences in the bending stiffness, whereas no differences in the ultimate moment capacity were detected between the two groups.

\section{Conclusions}

The final conclusions reached are as follows:

- The simple reinforcement tested (1.07\% GFRP reinforcement) can increase the bending stiffness of a beam by up to $12.1 \%$ and the ultimate moment by up to $17.9 \%$. The double reinforcement tested (1.6\% GFRP reinforcement) can increase the flexural stiffness of a beam by up to $14.7 \%$ and the ultimate moment by up to $23.4 \%$.

- The theoretical increase in bending stiffness is $3.3 \%$ and $6.1 \%$, while the experimental improvement was $12.1 \%$ and $14.7 \%$. This is because GFRP reinforcement homogenises the features of wood and reduces the effects of knots, cracks, and other defects.

- Reinforced beams showed larger ultimate deformations, and as a result, greater tensile strains and stresses in the wood. The average ultimate stress in wood increased by $17-19 \%$. The incorporation of GFRP reinforcement decreases the variability of the mechanical properties of the beams strength, and reduces the incidence of defects and irregularities in the wood.
- GFRP-reinforced beams can withstand an ultimate load that is 1.24 times greater than the ultimate load withstood by unreinforced beams. However, varying the amount of GFRP reinforcement does not result in a significant improvement in the ultimate load.

- GFRP-reinforced laminated beams of low-grade and rapidgrowth woods, such as poplar, have mechanical properties that are competitive with those of high-grade timber beams. The low cost of GFRPs compared to other types of reinforcement (such as CFRPs) offers a potential commercial development of this type of GFRP + wood duo structural element.

\section{Acknowledgements}

This project received funding from the Ministry of Science and Innovation of the Government of Spain through the subprogramme Fundamental Research Projects Not Oriented, 20132015 (BIA2012-31233) and also from the regional government Junta de Castilla y León (ref. VA051A10-2). The authors would also like to thank SIKA.

\section{References}

[1] C.E. Bakis, L.C. Bank, V.L. Brown, E. Cosenza, J.L. Davalos, J.J. Lesko, A. Machida, S.H. Rizkalla, T.C. Triantafillou, Fiber-reinforced polymer composites for construction - state of the art review, J. Compos. Constr. 6:2 (73) (2002) 7387, http://dx.doi.org/10.1061/(ASCE)1090-0268(2002)6:2(73).

[2] S. Thelanderson, H.J. Larsen, Timber Engineering, London, 2003.

[3] A. Parvez, The reinforcement of timber for structural applications and repair (PhD thesis), Dept Mech Eng University of Bath, 2004.

[4] L.A. Basterra, L. Acuña, G. Casado, G. Lopez, A. Bueno, Strength testing of Poplar duo beams, Populus $\times$ euramericana (Dode) Guinier cv. I-214, with fiber reinforcement, Constr. Build. Mater. 36 (2012) 90-96, http://dx.doi.org/ 10.1016/j.conbuildmat.2012.05.001.

[5] Z.A. Martin, D.A. Tingley, Fire resistance of FRP reinforced glulam beams, in: Proc. World Conf. Timber Eng., Whistler, Canada, 2000.

[6] CNR-DT 201/2005 Guidelines for the design and construction of externally bonded FRP systems for strengthening existing structures. Timber Structures, National Research Council. Advisory Committee on Technical Recommendations for Construction, Rome, 2007.

[7] K.U. Schober, A.M. Harte, R. Kliger, R. Jockwer, Q. Xu, J.-F. Chen, FRP reinforcement of timber structures, Constr. Build. Mater. 97 (2015) 106-118, http://dx.doi.org/10.1016/j.conbuildmat.2015.06.020.

[8] F.H. Theakston, A feasibility study for strengthening timber beams with fiberglass, Can. Agric. Eng. (1965) 17-19.

[9] W.M. Bulleit, Reinforcement of wood materials: a review, Wood Fiber Sci. 16 (3) (1984) 391-397.

[10] J.M. Moulin, G. Pluvinage, P. Jodin, FGRG: fibreglass reinforced glulam - a new composite, Wood Sci. Technol. 24 (1990) 289-294, http://dx.doi.org/10.1007/ BF01153561.

[11] T.C. Triantafillou, N. Deskovic, Prestressed FRP sheets as external reinforcement of wood members, J. Struct. Eng. 118 (1992) 1270-1284, http://dx.doi.org/10.1061/(ASCE)0733-9445(1992) 118:5(1270).

[12] H.J. Dagher, T.E. Kimball, S.M. Shaler, B. Abdel-Magid, Effect of FRP Reinforcement on Low Grade Eastern Hemlock Glulams, in: Natl. Conf. Wood Transp. Struct., General Technical Report No. FPL-GTR-96, Madison, WI:USA, 1996, pp. 207-214

[13] D.A. Tingley, The Stress-Strain Relationships in Wood and Fiber-Reinforced Plastic Laminae of Reinforced Glued-Laminated Wood Beams, Oregon State University, 1996. Availbale from: <http://hdl.handle.net/1957/18454>.

[14] R.C. Hernandez, R., Davalos, J.F. Sonti, S., Kim, Y., Moody, Strength and Stiffness of Reinforced Yellow-Poplar Glued-Laminated Beams, Madison, WI U.S. Dep. Agric. For. Serv. FPL-RP-554, 1997, p. 28.

[15] K.C. Johns, S. Lacroix, Composite reinforcement of timber in bending, Can. J. Civil Eng. 27 (5) (2000) 899-906, http://dx.doi.org/10.1139/100-017.

[16] J. Fiorelli, A. Alves Dias, Analysis of the strength and stiffness of timber beams reinforced with carbon fiber and glass fiber, Mater. Res. 6 (2003) 193-202, http://dx.doi.org/10.1590/S1516-14392003000200014.

[17] A. Borri, M. Corradi, A. Grazini, A method for flexural reinforcement of old wood beams with CFRP materials, Compos. Part B 36 (2005) 143-153, http:// dx.doi.org/10.1016/j.compositesb.2004.04.013.

[18] Y. Nadir, P. Nagarajan, M. Ameen, M.M. Arif, Flexural stiffness and strength enhancement of horizontally glued laminated wood beams with GFRP and CFRP composite sheets, Constr. Build. Mater. 112 (2016) 547-555, http://dx. doi.org/10.1016/j.conbuildmat.2016.02.133.

[19] C. Gentile, D. Svecova, S.H. Rizkalla, Timber beams strengthened with GFRP bars: development and applications, J. Compos. Constr. 6 (2002) 11-20, http:// dx.doi.org/10.1061/(ASCE)1090-0268(2002) 6:1(11). 
920

L.A. Basterra et al./Construction and Building Materials 154 (2017) 914-920

[20] K.U. Schober, K. Rautenstrauch, Experimental investigations on flexural strengthening of timber structures with CFRP, in: Proc. Int. Symp. Bond Behav. FRP Struct. (BBFS 2005), 2005, pp. 457-464.

[21] J. Jasieńko, T. Nowak, Strengthening of Bent Timber Beams in Historical Objects, in: From Mater. to Struct. - Mech. Behav. Fail. Timber Struct. ICOMOS IWC, Florence, Venice and Vicenza, 2007.

[22] R. Kliger, M. Al-Emrani, M. Johansson, R. Crocetti. Strengthening glulam beams with steel or CFRP plates, in: S.T. Smith (Ed.), Asia-Pacific Conf. FRP Struct. (APFIS 2007), 2007.

[23] A.S. Ribeiro, A.M.P. De Jesús, A.M. Lima, J.L.C. Lousada, Study of strengthening solutions for glued-laminated wood beams of maritime pine wood, Constr. Build. Mater. 23 (2009) 2738-2745, http://dx.doi.org/10.1016/ j.conbuildmat.2009.02.042.

[24] P. Alam, M.P. Ansell, D. Smedley, Mechanical repair of timber beams fractured in flexure using bonded-in reinforcements, Composites Part B 40 (2009) 95106, http://dx.doi.org/10.1016/j.compositesb.2008.11.010.

[25] G.M. Raftery, A.M. Harte, Low-grade glued laminated timber reinforced with FRP plate, Composites Part B 42 (2011) 724-735, http://dx.doi.org/10.1016/ j.compositesb.2011.01.029.

[26] J. Fiorelli, A. Alves Dias, Glulam beams reinforced with FRP externally-bonded: theoretical and experimental evaluation, Mater. Struct. 44 (2011) 1431-1440, http://dx.doi.org/10.1617/s11527-011-9708-y.

[27] G.M. Raftery, C. Whelan, Low-grade glued laminated timber beams reinforced using improved arrangements of bonded-in GFRP rods, Constr. Build. Mater. 52 (2014) 209-220, http://dx.doi.org/10.1016/j.conbuildmat.2013.11.044.
[28] M. Fossetti, G. Minafo, M. Papia, Flexural behavior of glulam timber beams reinforced with FRP cords, Constr. Build. Mater. 95 (2015) 54-64, http://dx.doi. org/10.1016/j.conbuildmat.2015.07.116.

[29] G.M. Raftery, F. Kelly, Basalt FRP rods for reinforcement and repair of timber, Composites Part B 70 (2015) 9-19, http://dx.doi.org/10.1016/ j.compositesb.2014.10.036.

[30] H. Yang, W. Liu, W. Lu, S. Zhu, Q. Geng, Flexural behavior of FRP and steel reinforced glulam beams: experimental and theoretical evaluation, Constr. Build. Mater. 106 (2016) 550-563, http://dx.doi.org/10.1016/ j.conbuildmat.2015.12.135.

[31] M. Casado, L. Acuña, L.A. Basterra, G. Ramón-Cueto, D. Vecilla, Grading of structural timber of Populus $\times$ euroamericana clone I-214, Holzforschung 66-5 (2012) 633-638, http://dx.doi.org/10.1515/hf-2011-0153.

[32] EN 13183:2002 Moisture content of a piece of sawn timber.

[33] EN 384:2010 Structural timber - Determination of characteristic values of mechanical properties and density.

[34] ISO 527-5:2009 Plastics. Determination of tensile properties. Part 5: Test conditions for unidirectional fibre-reinforced plastic composites.

[35] EN 56543:1988 Physical and mechanical properties of wood. Determination of shear stress.

[36] EN 408:2011 Timber structures - Structural timber and glued laminated timber. Determination of some physical and mechanical properties.

[37] A. Franke, B. Franke, A.M. Harte, Failure modes and reinforcement techniques for timber beams - state of the art, Mater. Struct. 97 (2015) 2-13, http://dx. doi.org/10.1016/j.conbuildmat.2015.06.021. 